\title{
Risk of death from cardiovascular disease and chronic bronchitis determined by place of birth in England and Wales
}

\author{
C Osmond, D J P Barker, J M Slattery
}

\begin{abstract}
Study objective-The aim of the study was to examine the relation between place of birth within England and Wales and cause of death.
\end{abstract}

Design-The study was a population survey using data provided by the Office of Population Censuses and Surveys which, for a trial period between 1969 and 1972, coded place of birth on death certificates.

Setting-The survey involved almost 2 million people who died in England and Wales between April 1969 and December 1972.

Main results-Persons born in northern counties and industrial towns, and in Wales, had increased risk of ischaemic heart disease and stroke, which persisted whether or not they had moved to other parts of the country. A low risk of cardiovascular disease among people born in and around London went with them when they moved. People born in cities and large towns had an increased and persisting risk of chronic bronchitis.

Conclusions-These findings are evidence that past geographical differences in fetal and infant growth, and in exposure to respiratory infection in early childhood, partly determine today's differences in adult death rates.

The environment in intrauterine life and early childhood may influence adult health more than has previously been supposed. ${ }^{12}$ Evidence for this comes mainly from epidemiological studies, and the underlying processes are not well understood.

In the early years of this century, when people now dying in middle and late life were born, there were large differences in the early environment between one part of Britain and another. These were determined by differences in the health and physique of mothers, infant rearing practices, overcrowding in the home, and population density. ${ }^{34}$ The effects on child growth and health were reflected in large differences in child mortality. In 1911-15, for example, infant mortality ranged from 68 per 1000 births in rural Sussex to 171 in Burnley.

If the environment in early life has an important effect, a person's risk of disease will be predicted by place of birth. This can be explored by examining disease rates in people who migrate from their place of birth, since the effects of the environment in early life can be distinguished from that encountered later on. Disease in migrants can be analysed using data from death certificates because place of birth is recorded. We have analysed cause of death in two million people born in England and Wales, half of whom migrated to another part of the country during their lives.

We present findings for ischaemic heart disease, stroke and chronic bronchitis. Death rates from each of these serve as a useful indicator of incidence, and numbers of deaths are sufficient to allow detailed geographical analysis. Death rates from ischaemic heart disease and stroke are higher in the north and west of the country, while for chronic bronchitis they are higher in the towns. There is epidemiological evidence that the early life environment is important in all three diseases. $^{156}$ In bronchitis the evidence is supported by studies of migrants from one country to another. ${ }^{7}$ Among British born men who migrated to the United States the prevalence of chronic bronchitis, after allowing for smoking habits, was higher than among migrants from Norway. It was higher among those born in urban areas of Britain and was unrelated to age at migration.

\section{Methods}

Place of birth within England and Wales is recorded on death certificates, but not routinely coded. For a trial period from April 1969 to December 1972, however, the Office of Population Censuses and Surveys (OPCS) did code the place of birth. These data, which have not been analysed before, were made available to us. There were 1907999 deaths in England and Wales among people who were also born there. For each death we had seven items of information; place of birth, place of usual residence at time of death, sex, age at death in years, year of death, underlying cause of death coded to the eighth revision of the International Classification of Diseases (ICD), and occupation (for 1970-1972 only, used to estimate social class).

Place of birth and death were coded to the $\mathbf{8 0}$ county boroughs, that is large towns, 15 London boroughs, and 57 administrative counties, which together comprise England and Wales. The OPCS coded Montgomeryshire and Radnorshire administrative counties identically; and births in Rutlandshire administrative county were coded as occurring in Leicestershire administrative county. Some places of birth were given as "London" without specifying the borough, and were analysed separately. The analyses were therefore based on 153 areas.

We grouped ages at death into 10 year bands, from 0 to 9 up to 90 and over. We ignored year of 
death because the data spanned less than four years. We analysed death from ischaemic heart disease (ICD 410-414), stroke (ICD 431-438) and chronic bronchitis (ICD 490-492).

The place where each individual lived was known only at birth and death. There was no denominator to calculate death rates for those who were born in one area and died in another, and we therefore used the proportion of all deaths that were due to each cause. To explore how these proportions varied according to birthplace and place of death we used a log-linear regression. ${ }^{8}$ For each disease and place this gave two numbers which were based on proportions of deaths in each age, sex and social class stratum. These represented the effect on the disease of either birth or death in that place. We refer to the numbers as the "place of birth" and the "place of death" effects. Their average value is 1.00 .

Results for men and women were similar. We used deaths from stomach cancer, which show a steep social class gradient, ${ }^{9}$ to explore the effect of social class on place of birth effects. Values after adjustment for social class were similar to those unadjusted, the largest differences being 0.01 . We therefore present unadjusted values for men and women combined.

Table I $\chi^{2}$ statistics with 152 degrees of freedom, for strength of place of birth effects: values exceeding 189 are statistically significant at the $5 \%$ level

\begin{tabular}{lccc}
\hline & $\begin{array}{c}\text { Ischaemic } \\
\text { heart disease }\end{array}$ & Stroke & $\begin{array}{c}\text { Chronic } \\
\text { bronchitis }\end{array}$ \\
\hline Independent & 1547 & 2077 & 2242 \\
Joint & 587 & 567 & 522 \\
Conditional & 320 & 372 & 327 \\
\hline
\end{tabular}

Table II Areas with place of birth effects for ischaemic heart disease, stroke and chronic bronchitis in the bottom tenth of the distribution and statistically significantly different from unity

\begin{tabular}{|c|c|c|}
\hline $\begin{array}{l}\text { Ischaemic } \\
\text { heart disease }\end{array}$ & Stroke & $\begin{array}{l}\text { Chronic } \\
\text { bronchitis }\end{array}$ \\
\hline $\begin{array}{l}\text { Bournemouth CB } \\
\text { Great Yarmouth CB } \\
\text { Nottingham CB } \\
\text { Anglesey AC } \\
\text { Caernarvonshire AC } \\
\text { Somerset AC } \\
\text { Sussex East AC } \\
\text { Sussex West AC } \\
\text { Wight, Isle of AC }\end{array}$ & $\begin{array}{l}\text { Birkenhead CB } \\
\text { Bootle CB } \\
\text { Burnley CB } \\
\text { Dudley CB } \\
\text { Grimsby CB } \\
\text { Camden LB } \\
\text { Hackney LB } \\
\text { Hammersmith LB } \\
\text { Lewisham LB } \\
\text { Newham LB } \\
\text { Southwark LB } \\
\text { Tower Hamlets LB } \\
\text { Westminster LB }\end{array}$ & $\begin{array}{l}\text { Bradford CB } \\
\text { Halifax CB } \\
\text { Norwich CB } \\
\text { Essex AC } \\
\text { Lincs (Kesteven) AC } \\
\text { Norfolk AC } \\
\text { Yorkshire E Riding AC }\end{array}$ \\
\hline
\end{tabular}

$\mathrm{CB}=$ county borough; $\mathrm{AC}=$ administrative county; $\mathrm{LB}=$ London borough

Table III Areas with place of birth effects for ischaemic heart disease, stroke and chronic bronchitis in the top tenth of the distribution and statistically significantly different from unity

\begin{tabular}{|c|c|c|}
\hline $\begin{array}{l}\text { Ischaemic } \\
\text { heart disease }\end{array}$ & Stroke & $\begin{array}{l}\text { Chronic } \\
\text { bronchitis }\end{array}$ \\
\hline $\begin{array}{l}\text { Bradford CB } \\
\text { Dewsbury CB } \\
\text { Halifax CB } \\
\text { Huddersfield CB } \\
\text { Preston CB } \\
\text { Cardiganshire AC } \\
\text { Carmarthenshire AC } \\
\text { Cumberland AC } \\
\text { Northumberland AC } \\
\text { Westmorland AC } \\
\text { Yorkshire W Riding AC }\end{array}$ & $\begin{array}{l}\text { Blackburn CB } \\
\text { Preston CB } \\
\text { Southport CB } \\
\text { Wigan CB } \\
\text { Anglesey AC } \\
\text { Cambridgeshire AC } \\
\text { Denbighshire AC } \\
\text { Lincs (Kesteven) AC } \\
\text { Northamptonshire AC } \\
\text { Yorkshire N Riding AC }\end{array}$ & $\begin{array}{l}\text { Birkenhead CB } \\
\text { Cardiff CB } \\
\text { Grimsby CB } \\
\text { Hastings CB } \\
\text { St Helens CB } \\
\text { Stockport CB } \\
\text { Warley CB } \\
\text { Wigan CB } \\
\text { Westminster LB } \\
\text { Glamorganshire AC } \\
\text { Monmouthshire AC }\end{array}$ \\
\hline
\end{tabular}

$\overline{\mathrm{CB}}=$ county borough; $\mathrm{AC}=$ administrative county; $\mathrm{LB}=$ London borough
The size of the place of birth effects does not necessarily represent the strength of their effect on disease risk. They are based on proportions of deaths from one cause in relation to all other causes. A high value may reflect deficits of deaths from other causes rather than a high risk associated with the place of birth. This is the fundamental disadvantage of proportional data analysis. The range of values taken by the place of birth effects is not immediately comparable across diseases which occur with different frequency, diseases which cause fewer deaths tending to have a greater range.

\section{Results}

From April 1969 to December 1972 there were 475547 deaths from ischaemic heart disease, 251565 from stroke and 94707 from chronic bronchitis among men and women who were born in England and Wales. For each disease there was a considerable spread in the place of birth effects. As predicted from the numbers of deaths from each cause the range of place of birth effects was smallest for ischaemic heart disease and highest for chronic bronchitis. The range for ischaemic heart disease was from 0.89 to 1.12 , for stroke from 0.86 to $1 \cdot 19$, and for chronic bronchitis from 0.83 to 1.24 .

We calculated $\chi^{2}$ statistics for the variation in place of birth effects both independently of and in relation to place of death effects (table I). The "joint" $\chi^{2}$ statistic was derived from the model. For the "conditional" statistic all possible variation was conceded to the place of death effect. Each disease had joint and conditional place of birth effects which were strongly statistically significant.

Tables II and III list places where the place of birth effects were in the bottom and top tenth of the distributions and were significantly different from unity using a test at the 5\% level. For ischaemic heart disease there were high place of birth effects in a number of industrial towns and counties in the north and west. The striking feature for stroke was the low place of birth effects in a group of London boroughs. For chronic bronchitis there were high place of birth effects in a group of towns and London boroughs and in two industrialised counties in South Wales.

We examined the relation between place of birth effects and standardised mortality ratios. To obtain stable estimates we calculated standardised mortality ratios for the 11 years $1968-78$, which is the period covered by the eighth revision of the ICD. For each cause of death the geographical distribution of place of birth effects correlated positively with the distribution of standardised mortality ratios. The correlation coefficients were 0.63 for ischaemic heart disease, 0.56 for stroke and 0.38 for chronic bronchitis. These correlations would have been influenced by use of an analysis based upon proportional mortality. For example, Burnley county borough had a low place of birth effect for stroke (table II), but a standardised mortality ratio of 120 . Because mortality ratios from other leading causes were even higher, the proportion of deaths due to stroke was below average, and the low place of birth effect is likely to reflect this. 


\section{Discussion}

This analysis of two million men and women, half of whom migrated from one part of England and Wales to another, shows that a person's risk of dying from ischaemic heart disease, stroke and chronic bronchitis is predicted by place of birth, independently of place of death. Part of the increased risk of ischaemic heart disease and stroke among people born in many northern counties and industrial towns, and in Wales, persists whether or not they move to other areas of the country. The low risk of cardiovascular disease, especially stroke, among people born in and around London goes with them when they move. People born in cities and large towns have an increased and persisting risk of chronic bronchitis.

Our analysis had to be based on the proportion of all deaths due to one cause, rather than on death rates. For the reasons given, the values of place of birth effects for each disease do not necessarily represent the strength of their effect on disease risk. The finding of a strong effect of birthplace on risk of chronic bronchitis is, however, consistent with a similar effect found in migrants from Britain to the United States. ${ }^{7}$ Additional analyses, to be published elsewhere, also show a strong effect of birthplace on risk of stomach cancer, another disease for which studies of international migrants show a large effect. ${ }^{9}$

Our results conflict with the conclusions of a recent analysis based on 43 episodes of ischaemic heart disease in 1177 middle aged men who migrated from one of three regions of England and Wales, or from Scotland, to another region. ${ }^{10}$ The absence of an important effect of place of birth in that analysis contrasts with the large effect we have observed for men and women, at all ages and in 153 areas. We have assigned our 153 areas to the three regions of England and Wales and find in our data that the independent, joint and conditional $\chi^{2}$ statistics (table I) all give values that are higher for place of birth than for place of death. In each region the proportion of deaths due to ischaemic heart disease is greatest among those born in the northern region.

Studies of migrants need careful interpretation since their risk of disease is unlikely to be representative of the populations they leave. Furthermore, in our study the place where each individual lived was known only at birth and death and we cannot determine the age at which the place of birth acts in the genesis of each disease. A place of birth effect could reflect predisposition to disease related to social customs that are acquired in childhood, but which migrants take with them and which act in later life, dietary customs for example. Place of birth effects could also reflect genetic variations in susceptibility, although the large changes in incidence of each of the diseases during this century point to the dominance of the environment in determining their distribution.

Other evidence suggests that, while influences on the adult environment such as cigarette smoking are important, the environment in early life also has a major effect on the risk of cardiovascular disease and chronic bronchitis. The geographical distribution of cardiovascular mortality throughout England and Wales is closely related to maternal and neonatal mortality 70 and more years ago. ${ }^{11}$ The effect of place of birth may therefore depend on past differences in maternal health and fetal and infant growth. Blood pressure levels in adult life are inversely related to fetal growth and are one possible link between birthplace and cardiovascular risk. ${ }^{12}$

The effect of birthplace on the risk of chronic bronchitis may be determined by past differences in the incidence of lower respiratory tract infection in early life. ${ }^{6}$ These in turn depended on differences in housing, family size, crowding in the home and infant feeding. Evidence that childhood respiratory function is causally linked to chronic bronchitis comes from prospective studies showing that lower respiratory infection before the age of two may be followed by respiratory symptoms and abnormalities of pulmonary function in later childhood and early adult life. ${ }^{13-16}$

This analysis of one million people who moved from one part of England and Wales to another is further evidence that the environment in intrauterine life and early childhood has a larger effect on adult cardiovascular disease than has previously been supposed, and partly determines today's geographical inequalities in health. Measurements of this effect must, however, await the results of prospective studies which are now in progress.

We are grateful to the Office of Population Censuses and Surveys for making these data available to us.

1 Barker DJP, Osmond C. Infant mortality, childhood nutrition, and ischaemic heart disease in England nutrition, and ischaemic heart
Wales. Lancet 1986; i: 1077-81

2 Barker DJP. Rise and fall of Western disease. Nature 1989 338: 371-2.

3 Local Government Board. 42nd annual report, 1912-13. Supplement in continuation of the report of the medica officer of the board for 1912-13. London: His Majesty's Stationery Office, 1913.

4 Campbell JM. Maternal mortality. (Ministry of Health Reports on Public Health and Medical subjects, No. 25). Leports on Public Health and Medical subjects,

5 Barker DJP, Osmond C. Death rates from stroke in England and Wales predicted from past maternal mortality. $\mathrm{Br} \mathrm{Med} \mathcal{F}$ 1987; 295: 83-6.

6 Barker DJP, Osmond C. Childhood respiratory infection and adult chronic bronchitis in England and Wales. $B r$ Med F 1986; 293: 1271-5.

7 Reid DD, Fletcher CM. International studies in chronic respiratory disease. Br Med Bull 1971; 27: 59-64.

8 Osmond C, Slattery JM, Barker DJP. Mortality by place of birth. In: Mortality and geography. Office of Population Censuses and Surveys Decennial Supplement No. 9. London: Her Majesty's Stationery Office, 1990.

9 London: Her Majesty's Stationery Office, 1990. stomach. Br Med Bull 1984; 40: 335-41.

10 Elford J, Phillips AN, Thomson AG, Shaper AG. Migration and geographic variations in ischaemic heart disease in Great Britain. Lancet 1989; i: 343-6.

11 Barker DJP, Osmond C, Law CM. The intrauterine and early postnatal origins of cardiovascular disease and chronic bronchitis. F Epidemiol Community Health 1989; 43: $237-40$.

12 Barker DJP, Osmond C, Golding J, Kuh D, Wadsworth MEJ. Growth in utero, blood pressure in childhood and adult life, and mortality from cardiovascular disease. Br Med f 1989, 298: 564-7.

13 Gurwitz D, Mindorff C, Levison H. Increased incidence of bronchial reactivity in children with a history of bronchiolitis. Pediatrics 1981; 98: 551-5.

14 Pullan CR, Hey EN. Wheezing, asthma, and pulmonary dysfunction 10 years after infection with respiratory syncytial virus in infancy. $B r$ Med $\mathcal{f} 1982 ; 284$ : 1665-9.

15 Mok JYQ, Simpson H. Outcome of acute bronchitis, bronchiolitis, and pneumonia in infancy. Arch Dis Child 1984; 59: 306-9.

16 Kiernan KE, Colley JRT, Douglas JWB, Reid DD. Chronic cough in young adults in relation to smoking habits, childhood environment and chest illness. Respiration 1976; 